\title{
Faktor Psikososial dan Aktivitas Kerja pada Perawat ICU serta ICCU dengan Nyeri Punggung Bawah
}

\author{
Gandu Eko Julianto Suyoso \\ Program Studi Rekam Medik, Jurusan Kesehatan, Politeknik Negeri Jember,gandu.eko.js@polije.ac.id
}

\begin{abstract}
ABSTRAK
Latar belakang: Nyeri Punggung bawah masih menjadi salah satu gangguan muskuloskeletal yang dialami oleh perawat. Nyeri punggung bawah disebabkan oleh banyak faktor secara parsial ataupun simultan. Beberapa diantara faktor tersebut adalah faktor psikososial dan faktor aktivitas pekerjaan. Faktor psikososial yang dimaksud terdiri dari tuntutan kerja, kendali kerja, dukungan sosial dan kepuasan kerja. Sedangkan faktor aktivitas fisik pekerjaan yang diteliti adalah aktivitas pemindahan pasien secara lateral. Faktor faktor tersebut masih diabaikan oleh sebagian pengelola rumah sakit. Tujuan: Penelitian ini bertujuan untuk menganalisis hubungan faktor psikososial serta faktor aktivitas fisik pekerjaan dengan keluhan nyeri punggung bawah perawat ICU (Intensive Care Unit) dan ICCU (Intensive Cardiologi Care Unit). Metode penelitian: Desain penelitian kuantitatif ini berjenis cross sectional. Data faktor psikososial perawat diperoleh melalui kuesioner yang mengadopsi General Nordic Questionairre (QPSNORDIC) dan MJS (Measure of Job Satisfaction). Data faktor aktivitas fisik pekerjaan diperoleh melalui observasi dengan metode skoring REBA (Rapid Entire Body Assessment). Analisis bivariat melalui uji koefisien kontingensi digunakan untuk mencari kuat hubungan antara variabel. Hasil penelitian: Didapatkan bahwa keluhan nyeri bawah punggung memiliki: hubungan dengan persepsi perawat tentang tuntutan kerja $(r=0,414)$, persepsi perawat tentang dukungan sosial $(r=0,510)$, persepsi perawat tentang kendali kerja ( $r=$ $0,333)$, kepuasan kerja $(r=0,401)$, aktivitas pemindahan pasien secara lateral $(r=0,439)$. Simpulan: Keluhan nyeri pungggung bawah memiliki hubungan yang kuat dengan persepsi perawat tentang tuntutan kerja, persepsi perawat tentang dukungan sosial, kepuasan kerja, aktivitas pemindahan pasien secara lateral; hubungan yang lemah dengan persepsi perawat tentang kendali kerja.
\end{abstract}

Kata kunci: Nyeri Punggung Bawah, Perawat, Psikososial, Aktivitas pekerjaan

\begin{abstract}
Background: Low back pain is one of many musculosceletal disorder that were still suffered by nurses. Low back pain caused by many factor, partially or simultaneuosly. Some of those factor are psychosocial factor and occupational activity factor. Psychosocial factor consisted of job demand, job control, social support and job satisfaction. Occupational activity factor in this study is lateral patient transfer. Those factor are still neglected by some of hospital employer. Purpose: The aim of this study was to analyze the association of psychosocial factor (job demand, job control, job satisfaction, social control), occupational activity control (lateral patient transfer) and nurse's low back pain. Methods: This cross sectional study held in ICU and ICCU unit at 3 hospital in Jember. Data was collected through questionairres that adopted General Nordic Questionairre (QPSNORDIC) also MJS (Measure of Job Satisfaction) and through observation by utilized REBA (Rapid Entire Body Assessment) scoring method. Results: Bivariat analysis showed that nurse's low back pain have association with nurse perception about job demand $(r=0,414)$, nurse perception about social support $(r=0,510)$, nurse perception about job satisfaction $(p=0,401)$, association with nurse perception about job control $(r=0,333)$, lateral patient transfer $(r=0,439)$. Conclusion: Nurses Low Back Pain have a strong association with nurse perception about job demand, nurse perception about social support, nurse perception about job satisfaction; a weak association with nurse perception about job control.
\end{abstract}

Keywords: Low back pain, Nurses, Psychosocial, Occupational Activity

*Korespondensi Author : Gandu Eko Julianto Suyoso, Politeknik Negeri Jember, gandu.eko,js@gmail.com, Telp.0811355955 


\section{PENDAHULUAN}

Nyeri punggung bawah non spesifik telah menjadi masalah kesehatan umum yang mendunia ${ }^{1}$. Prevalensi dari nyeri punggung bawah dilaporkan sebesar $84 \%{ }^{2} \quad$ Nyeri punggung bawah juga merupakan masalah kesehatan yang mempengaruhi dunia kerja, yang berakibat pada disabilitas, penggunaan fasilitas kesehatan dan beban sosial ekonomi yang berat ${ }^{3}$. Paparan bahaya di lingkungan kerjanya menyebabkan perawat memiliki resiko lebih tinggi mengalami nyeri punggung daripada pekerjaan lain. ${ }^{4}$ Prevalensi gejala muskuloskeletal tertinggi yang dialami perawat di Amerika serikat, antara lain punggung bawah, pundak dan ekstrimitas bawah. ${ }^{5}$ Dari 1600 pekerja di enam rumah sakit di Turki, 65,8 persen diantaranya pernah mengalami nyeri punggung bawah dalam 12 bulan terakhir. Prevalensi tertinggi pada perawat $(77,1 \%)$ dan terendah adalah pada administrasi (54,1\%). Sebagian besar orang yang mengalami nyeri punggung bawah akan mengalami episode rekuren dengan angka estimasi dalam setahun sebesar 24 persen hingga 80 persen. $^{2}$

Nyeri punggung bawah tidak dianggap sebagai masalah yang sangat penting bila dibandingkan dengan penyakit kardiovaskular atau keganasan, nyeri pungung bawah sangat sering terjadi dan membutuhkan biaya yang cukup besar untuk mengatasinya. ${ }^{6}$ Total biaya langsung yang dikeluarkan karena nyeri punggung bawah pertahunnya adalah sebesar 7000 euro. Tercatat Work absenteism sebesar 75 persen dari total biaya terapi nyeri punggung bawah per pasien. ${ }^{7}$ Data dari statistik departemen tenaga kerja Amerika serikat menunjukkan asisten perawat dan perawat menempati peringkat ke 3 dan ke 6 hilangnya hari kerja karena gangguan muskuloskeletal (termasuk hari kerja hilang karena nyeri punggung $)^{4}$. Namun dampak dari presenteism karena nyeri punggung bawah ternyata bisa mencapai 7,5 kali dari absenteism karena berkurangnya produktivitas. ${ }^{8}$
Nyeri punggung bawah merupakan salah satu dari beberapa keluhan muskuloskeletal yang ditandai dengan gejala nyeri berlokasi di antara rusuk ke 12 dan lipatan gluteal inferior dengan atau tanpa disertai nyeri pada kaki salah satu, disebabkan oleh berbagai faktor, beberapa faktor secara singular atau kombinasi berkontribusi pada timbulnya kondisi tersebut. ${ }^{9,10}$ Faktor tersebut antara lain faktor personal, psikososial pekerjaan, dan aktivitas fisik pekerjaan. ${ }^{11,12,13}$ Kesehatan perawat tidak saja mempengaruhi kepuasan kerja mereka, kualitas hidup dan keinginan untuk merubah pekerjaan namun juga kualitas pelayanan dan keselamatan pasien. Pada penelitian sebelumnya di 3 Rumah Sakit di Kabupaten Jember, telah dilakukan penelitian untuk menganalisis hubungan faktor personal perawat ICU dan ICCU dengan keluhan nyeri punggung bawah. Mengingat pentingnya kesehatan perawat tersebut dan kompleksnya faktor penyebabnya, maka perlu dilakukan penelitian lanjutan tentang hubungan faktor psikososial dan faktor aktivitas pekerjaan perawat dengan keluhan nyeri punggung bawah.

\section{METODOLOGI}

Penelitian ini merupakan penelitian kuantitatif yang bersifat survei analitik dengan desain penelitian cross sectional untuk menganalisis pengaruh faktor fisik pekerjaan, psikososial dan personal nyeri punggung bawah perawat di 3 rumah sakit. Populasi penelitian ini adalah semua perawat ICCU dan ICU di Rumah sakit XYZ yang berjumlah 41 orang. Sampel penelitian ini adalah 41 orang perawat tersebut.

Data yang diperoleh dari hasil penelitian ini yaitu bersumber dari data primer. Data primer didapatkan dari hasil kuesioner. Keluhan nyeri punggung bawah perawat ICU dan ICCU digali menggunakan kuesioner yang mengadopsi pertanyaan yang ada pada Standar Nordic Questionairre for Low Back Pain. Kuesioner tentang persepsi perawat tentang faktor psikososial terdiri dari 4 sub bagian yaitu tuntutan kerja, kendali kerja, dukungan sosial 
dan kepuasan kerja. Pertanyaan mengenai persepsi perawat terhadap tuntutan kerja, kendali kerja dan dukungan sosial merupakan pertanyaan yang diadopsi dari kuesioner General Nordic Questionairre (QPSNORDIC), sedangkan pertanyaan mengenai persepsi kepuasan kerja perawat diadopsi dari MJS (Measure of Job Satisfaction). Penilaian didapatkan berdasarkan hasil perhitungan total skor skala likert pada kuesioner tersebut. Kuesioner diuji terlebih dahulu dengan Uji Korelasi Pearson dan Uji Cronbach Alpha untuk mendapatkan standar validitas dan reliabilitas. Data primer aktivitas pekerjaan perawat ICU dan ICCU didapatkan melalui observasi menggunakan instrument skoring REBA (Rapid Entire Body Assessment). Data primer keluhan nyeri punggung bawah perawat didapatkan menggunakan kuesioner Standar Nordic Questionnaire for low back pain.

Selanjutnya data yang diperoleh dianalisis bivariat dengan uji koefisien kontingensi dan uji $t$ independent untuk mencari hubungan variabel independen terhadap variabel dependen

\section{HASIL DAN PEMBAHASAN}

Data distribusi nyeri punggung perawat ICU dan ICCU berdasarkan kategori persepsi tentang masing masing variabel psikososial tertera pada tabel berikut.

Tabel 1. Distribusi Nyeri Punggung Bawah Perawat ICU dan ICCU berdasarkan Kategori Persepsi Variabel Psikososial

\begin{tabular}{|c|c|c|}
\hline \multirow{2}{*}{$\begin{array}{l}\text { Persepsi tentang } \\
\text { tuntutan kerja }\end{array}$} & \multicolumn{2}{|c|}{ Nyeri punggung bawah } \\
\hline & Ya (\%) & Tidak(\%) \\
\hline Rendah & $\begin{array}{c}10 \\
(35.7 \%\end{array}$ & $\begin{array}{c}11 \\
(84.6 \%)\end{array}$ \\
\hline Tinggi & $\begin{array}{c}18 \\
(64,3 \%)\end{array}$ & $\begin{array}{c}2 \\
(15,4 \%)\end{array}$ \\
\hline Jumlah (\%) & $\begin{array}{c}28 \\
(100 \%)\end{array}$ & $\begin{array}{c}13 \\
(100 \%)\end{array}$ \\
\hline \multirow{2}{*}{$\begin{array}{l}\text { Persepsi tentang } \\
\text { kendali kerja }\end{array}$} & \multicolumn{2}{|c|}{ Nyeri punggung bawah } \\
\hline & Ya (\%) & Tidak(\%) \\
\hline Rendah & $\begin{array}{c}21 \\
(75 \%) \\
\end{array}$ & $\begin{array}{c}5 \\
(38,5 \%) \\
\end{array}$ \\
\hline Tinggi & $\begin{array}{c}7 \\
(25 \%) \\
\end{array}$ & $\begin{array}{c}8 \\
(61,5 \%) \\
\end{array}$ \\
\hline
\end{tabular}

\begin{tabular}{|c|c|c|}
\hline Jumlah $(\%)$ & $\begin{array}{c}28 \\
(100 \%)\end{array}$ & $\begin{array}{c}13 \\
(100 \%)\end{array}$ \\
\hline \multirow{2}{*}{$\begin{array}{l}\text { Persepsi tentang } \\
\text { dukungan sosial }\end{array}$} & \multicolumn{2}{|c|}{ Nyeri punggung bawah } \\
\hline & Ya (\%) & Tidak(\%) \\
\hline Rendah & $\begin{array}{c}20 \\
(71,4 \%) \\
\end{array}$ & $\begin{array}{c}1 \\
(7,7 \%) \\
\end{array}$ \\
\hline Tinggi & $\begin{array}{c}8 \\
(28,6 \%) \\
\end{array}$ & $\begin{array}{c}12 \\
(92,3 \%) \\
\end{array}$ \\
\hline Jumlah (\%) & $\begin{array}{c}28 \\
(100 \%)\end{array}$ & $\begin{array}{c}13 \\
(100 \%)\end{array}$ \\
\hline \multirow{2}{*}{$\begin{array}{l}\text { Persepsi tentang } \\
\text { kepuasan kerja }\end{array}$} & \multicolumn{2}{|c|}{ Nyeri punggung bawah } \\
\hline & Ya (\%) & Tidak(\%) \\
\hline Rendah & $\begin{array}{c}15 \\
(53,6 \%) \\
\end{array}$ & $\begin{array}{c}1 \\
(7,7 \%) \\
\end{array}$ \\
\hline Tinggi & $\begin{array}{c}13 \\
(46,4 \%) \\
\end{array}$ & $\begin{array}{c}12 \\
(92,3 \%) \\
\end{array}$ \\
\hline Jumlah $(\%)$ & $\begin{array}{c}28 \\
(100 \%)\end{array}$ & $\begin{array}{c}13 \\
(100 \%)\end{array}$ \\
\hline
\end{tabular}

Pada tabel 1 diketahui bahwa mayoritas perawat yang mengalami nyeri punggung bawah adalah perawat dengan persepsi tentang tuntutan kerja yang tinggi, kendali kerja yang rendah, dukungan sosial yang rendah, dan kepuasan kerja yang rendah. Setelah dilakukan uji koefisien kontingensi pada data variabel psikososial yang diperoleh melalui kuesioner, didapatkan hasil sebagai berikut:

Tabel 2. Hasil Uji Koefisien Kontigensi

Variabel Persepsi Perawat ICU dan ICCU terhadap Variabel Psikososial terhadap Keluhan Nyeri Punggung Bawah

\begin{tabular}{lc}
\hline \multicolumn{1}{c}{ Variabel } & r \\
\hline Persepsi perawat tentang tuntutan kerja & 0,414 \\
\hline Persepsi perawat tentang kendali kerja & 0,333 \\
\hline Persepsi perawat tentang dukungan sosial & 0,510 \\
\hline Persepsi perawat tentang kepuasan kerja & 0,401 \\
\hline
\end{tabular}

Untuk mengkonfirmasi hasil uji koefisien kontingensi maka dilakukan pula uji $t$ independen pada masing-masing variabel psikososial..

Tabel 3. Hasil Uji t-Independen Variabel Persepsi Perawat ICU dan ICCU terhadap Variabel Psikososial terhadap Keluhan Nyeri Punggung Bawah

Variabel Rerata \pm Standar
deviasi 


\begin{tabular}{lcc}
\hline & $\begin{array}{c}\text { Mengalami } \\
\text { Nyeri } \\
\text { Punggung } \\
\text { Bawah } \\
(\mathbf{n = 2 8 )}\end{array}$ & $\begin{array}{c}\text { Tidak } \\
\text { Mengalami } \\
\text { Nyeri } \\
\text { Punggung } \\
\text { Bawah } \\
\text { (n=13) }\end{array}$ \\
\hline $\begin{array}{l}\text { Persepsi perawat } \\
\text { tentang tuntutan } \\
\text { kerja }\end{array}$ & $25,54 \pm 3,9$ & $22 \pm 3,6$ \\
\hline $\begin{array}{l}\text { Persepsi perawat } \\
\text { tentang kendali } \\
\text { kerja }\end{array}$ & $19,5 \pm 3,2$ & $22,3 \pm 3,6$ \\
\hline $\begin{array}{l}\text { Persepsi perawat } \\
\text { tentang dukungan } \\
\text { sosial }\end{array}$ & $21,5 \pm 3,9$ & $27,31 \pm 3,4$ \\
\hline $\begin{array}{l}\text { Persepsi perawat } \\
\text { tentang kepuasan } \\
\text { kerja }\end{array}$ & $26,7 \pm 5,1$ & $31,15 \pm 4,4$ \\
\hline
\end{tabular}

Pada tabel 2 diketahui bahwa keluhan nyeri bawah punggung yang dialami perawat memiliki: hubungan yang kuat dengan persepsi perawat tentang tuntutan kerja $(\mathrm{r}=0,414)$, persepsi perawat tentang dukungan sosial $(\mathrm{r}=0,510)$, kepuasan kerja $(\mathrm{p}=0,401)$; hubungan yang lemah dengan persepsi perawat tentang kendali kerja $(r=-0,333)$. Serta berdasarkan tabel 3 diketahui bahwa terdapat perbedaan rerata persepsi di semua variabel psikososial antara kelompok perawat yang mengalami nyeri punggung belakang dan kelompok perawat yang tidak mengalami nyeri punggung bawah.

Stresor psikososial pada dasarnya adalah suatu kondisi yang dipersepsikan sebagai kondisi mengancam, berbahaya atau mengganggu atau kondisi yang menuntut respon adaptasi fisiologis oleh pekerja. ${ }^{14}$

Terdapat beberapa model yang menjelaskan hubungan antara faktor psikososial pekerjaan dengan gangguan muskuloskeletal. Salah satunya adalah model ekologis yang dijelaskan oleh Sauter dan Swanson. Model ini berdasarkan pada gagasan bahwa faktor fisik dan psikokologis di tempat kerja berkontribusi pada gangguan muskuloskeletal. Model ini menjelaskan hubungan langsung antara beban fisik dan organisasi kerja, yang berarti bahwa beban fisik diperberat beban organisasi (misal : peningkatan spesifikasi kerja, peningkatan repetisi), serta hubungan langsung antara organisasi kerja dan ketegangan psikologis yang kemudian pada akhirnya mempengaruhi muskuloskeletal. Dalam menjelaskan hubungan tersebut, terdapat dua mekanisme untuk mempengaruhi dampak muskuloskeletal, Pertama, stres meningkatkan ketegangan otot dan proses autonomik yang menambahkannya ke ketegangan biomekanis yang sudah ada sebelumnya. Kedua, proses kognitif memediasi hubungan antara ketegangan biomekanis dan gejala muskuloskeletal. Rangsangan terkait stres dapat meningkatkan sensitivitas terhadap sensasi muskuloskeletal yang normal; pekerja menjadi lebih waspada terhadap sensasi kecil yang pada kondisi lain harusnya tidak terasa ${ }^{15}$.

Ide ini mirip dengan model stres transaksional yang dikemukan oleh Lazarus, bahwa ketegangan merupakan salah satu jalur utama yang digunakan oleh lingkungan dalam perannya mempengaruhi kesehatan. Model transaksional stres juga menjelaskan bahwa persepsi seseorang bisa mempengaruhi ketegangan yang dialami. Model stres transaksional menekankan pada pentingnya transaksi lingkungan-individu. Keduanya, model ekologis dan model transaksional memberikan dasar yang serupa mengenai peran ketegangan sebagai media antara stresor psikososial kerja dan gangguan muskuloskeletal terkait pekerjaan. ${ }^{16}$

Ada beberapa penelitian sebelumnya yang telah mengemukakan hubungan faktor psikososial dan gangguan muskuloskeletal. Satu meta-analisis, mengungkap ditemukan bukti yang konsisten tentang hubungan antara faktor psikososial dan gangguan muskuloskeletal pada perawat dan asisten perawat. ${ }^{17}$

Tuntutan kerja didefinisikan sebagai kapabilitas kerja secara umum yang dibutuhkan tenaga kerja untuk melaksanakan pekerjaan yang diberikan. Tuntutan kerja mengindikasikan seberapa berat pekerjaan yang dilakukan. ${ }^{18}$ Tuntutan kerja meliputi aspek psikologis dan fisik. Aspek psikologis dalam tuntutan kerja adalah berupa seberapa besar tugas tersebut membutuhkan stimulasi kognitif, kesiagaan mental dan kerja mental seperti pengolahan 
informasi, penyelesaian masalah, pengambilan keputusan dan organisasi serta koordinasi infromasi. Aspek fisik meliputi tugas yang membutuhkan kerja fisik seperti mengangkat beban berat bekerja dalam posisi tidak ergonomis dalam waktu yang lama atau bekerja dalam irama yang cepat. ${ }^{19}$ Ketika pekerja tidak mampu memenuhi tuntutan pekerjaan, maka akan memunculkan distres. ${ }^{20}$

Pada penelitian ini didapatkan bahwa persepsi perawat tentang tuntutan kerja dan nyeri punggung bawah punggung memiliki hubungan yang cukup kuat $(\mathrm{r}=0,414)$. Stresor psikososial terkait pekerjaan seperti tuntutan kerja yg tinggi dapat berpengaruh pada respon fisiologis pekerja. Bila respon ini mengalami pengulangan secara aktif karena paparan stresor yang terus menerus, lama kelamaan akan menimbulkan keluhan fisik seperti nyeri punggung bawah. ${ }^{21}$ Tuntutan kerja yang tinggi bila dikombinasikan dengan rendahnya dukungan sosial dapat meningkatkan gejala gangguan musculoskeletal. ${ }^{15}$

Tuntutan kerja keperawatan melibatkan volume pekerjaan yang harus diselesaikan (kuantitatif) dan tingkat kesulitan yang terjadi dalam pekerjaan (kualitatif). Stres kerja pada perawat terjadi karena adanya perbedaan yang muncul antara tuntutan kerja yang dialami perawat dan kemampuan untuk mengatasi hal tersebut. Kondisi stres yang berlebihan akan berakibat buruk terhadap kemampuan perawat untuk behubungan dengan lingkungannya secara normal. ${ }^{20}$

Perawat ICU dan ICCU merupakan perawat dengan keahlian khusus yang didapat dari pelatihan tertentu, karenanya jumlah perawat ICU dan ICCU terbatas. Jumlah perawat yang terbatas bila disertai beban kerja yang tinggi akan menyebabkan perawat lebih cepat lelah. Strategi kerja yang efektif melalui pembagian tugas yang berimbang, peningkatan kedisiplinan perawat dan peningkatan ketahanan fisik serta keterampilan perawat diperlukan untuk dapatnya memperbaiki tuntutan kerja perawat.
Istilah kendali kerja dalam beberapa studi sering diganti dengan istilah pemberian wewenang yang lebih merujuk pada distribusi kekuasaan. $^{22}$ Distribusi kekuasaan dalam organisasi bisa pada konsep tingkat individu atau tingkat organisasi. ${ }^{20}$ Konsep tentang kontrol pekerjaan melibatkan pembelajaran suatu hal baru, sedikit pekerjaan berulang, mendorong kreativitas dan pengembangan diri pekerja, variasi pekerjaan, kemampuan atau kewenangan seseorang untuk membuat keputusan sendiri atas pekerjaannya dan mempengaruhi kelompok kerja atau organisasi tempat dia bekerja. ${ }^{23,24}$. Kendali kerja yang lebih tinggi akan memungkinkan seseorang untuk mengambil tindakan alternatif sehingga dapat mereduksi efek stresor. ${ }^{23}$

Pada penelitian ini didapatkan bahwa hubungan persepsi perawat tentang kendali kerja dan nyeri punggung bawah punggung memiliki hubungan yang lemah $(\mathrm{r}=0,333)$. Perawat ICU dan ICCU di tiga RS XYZ sebagian besar memiliki kendali kerja rendah, sebagai perawat berkeahlian khusus tugas mereka tidak hanya memberikan asuhan keperawatan bagi pasien namun juga memberikan asistensi bagi tenaga medis lain di ruangan ICU dan ICCU.

Kendali kerja yang tinggi dapat melindungi pekerja dari timbulnya nyeri punggung bawah dengan berkurangnya jumlah ketegangan yang dialami pekerja, berkurangnya tegangan otot atau reaksi fisiologis lain yang bisa menyebabkan individu memiliki risiko tinggi mengalami gangguan muskuloskeletal terkait pekerjaan. ${ }^{20}$ Pekerja dengan kendali kerja tinggi lebih memiliki otonomi seperti bisa istirahat lebih sering, memulihkan ototnya dan mengurangi risiko gangguan musculoskeletal. ${ }^{16}$

Dukungan sosial merupakan bentuk penyediaan informasi berupa dukungan emosional sehingga individu merasa dikasihi dan diperhatikan, penghargaan yang mampu menegaskan kembali nilai seseorang dan dukungan jaringan yang menyediakan jaminan bagi seseorang untuk bisa mendapatkan bantuan dari anggota lain ketika berada dalam suatu masalah. ${ }^{25}$ Dukungan sosial di tempat kerja juga 
didefinisikan sebagai derajat di mana setiap individu merasakan kenyamanan dan dihargai ditempat kerja oleh supervisor dan organisasi yang lebih luas di mana mereka berada. ${ }^{26}$ Dukungan sosial merupakan salah satu faktor psikososial yang menyeimbangkan atau melindungi pekerja dari efek stresor situasi kerja yang tidak meyenangkan. ${ }^{19}$

Dukungan sosial dari rekan kerja atau atasan telah diteliti dalam berbagai populasi dan menunjukkan hasil yang konsisten. Pada penelitian ini didapatkan bahwa hubungan persepsi perawat tentang dukungan sosial dan nyeri punggung meimiliki hubungan yang cukup kuat $(\mathrm{r}=0,510)$. Persepsi terhadap dukungan sosial yang buruk berhubungan dengan peningkatan laporan gejala. Dalam suatu studi longitudinal, Bongers et al melaporkan tuntutan kerja yang tinggi bila dikombinasikan dengan rendahnya dukungan sosial dapat meningkatkan gejala gangguan musculoskeletal. ${ }^{15}$

Beberapa studi menyebutkan bahwa dukungan sosial berperan penting dalam menjaga kesehatan fisik dan psikologi. ${ }^{27}$ Terdapat dua macam model utama tentang bagaimana dukungan sosial dapat mempengaruhi kesehatan, yaitu model langsung/tidak langsung dan model penyangga (buffer). Model buffer merupakan model yang paling banyak digunakan dalam literatur yang membahas stres. Model ini memberi konsep bahwa dukungan sosial merupakan variabel yang dapat mempengaruhi hubungan antara stresor dan kesehatan. ${ }^{28}$ Dukungan sosial dapat mempengaruhi kemampuan coping seseorang. Salah satu metode dalam mempengaruhi kemampuan coping yaitu berupa pemberian alternatif strategi coping oleh anggota dalam sistem yang berdasarkan atas pengalaman si pemberi saran sendiri.

Ditinjau dari sisi neurofisiologis, dalam studi terhadap manusia, dukungan sosial yang rendah berhubungan dengan fisiologis dan neuroendokrin saat terjadi peningkatan respon stres. Dukungan sosial dapat merubah persepsi terhadap ancaman potensial. ${ }^{29}$ Perasaan diperhatikan dan didukung ini menyebabkan seseorang menjadi menilai kondisi tertentu bukan lagi menjadi ancaman, demikian sehingga mencegah onset reaktivitas stres fisiologis. Banyak studi tentang reaktivitas stres berfokus pada peran aksis hypothalamic-pituitaryadrenal (HPA) dalam menginduksi respon stres psikologis, namun ada bagian neural lain yang juga memiliki peran dalam memodulasi reaktivitas stres sebagai fungsi dari dukungan sosial. Karena sifat dukungan sosial menjadi regulator terhadap reaktivitas stres, dukungan sosial dapat berhubungan dengan sedikitnya aktivitas di struktur limbik yang biasanya berhubungan dengan respon terhadap pengalaman atau kondisi mengancam. Struktur tersebut adalah amygdala, insula atau anterior cingulate cortex (ACC). Amygdala merespon stimulus bahaya atau mengancam dan memiliki hubungan kuat dengan nukleus paraventricular dari hipotalamus yang memicu pelepasan kortisol, ini mengimplikasikan peran amygdala dalam memfasilitasi respon stres fisiologis. Insula dianggap terlibat dalam pemrosesan sensasi viscera. Kortek insula juga memiliki proyeksi ke nukelus sentral amygdala dan hipotalamus lateral serta memiliki peran dalam respon fisiologis yang menyertai pengalaman emosional. ACC, tergantung lokasi aktivitasnya terlibat dalam pengalaman afektif dan respon fisiologis terkait stres. Bagian dorsal dari ACC telah ditunjukkan terlibat dalam menghambat pengalaman terkait nyeri fisik. Individu yang mendapat dukungan sosial menunjukkan berkurangnya aktivitas dACC dan Area Broadman 8, serta berkurangnya reaktivitas kortisol. ${ }^{30}$

Perawat membutuhkan perhatian yang besar dari organisasi karena merupakan personil yang paling sering berhadapan dengan pasien. Banyak menghabiskan sebagian besar waktunya dengan pasien, sehingga apabila terjadi kesulitan-kesulitan dalam menjalankan tugasnya, mereka mengharapkan bantuan dari organisasi dengan menyediakan dukungan untuk membantu perawat dalam menyelesaikan tugasnya. Apabila dalam situasi sulit dan penuh tekanan, organisasi tidak dapat menyediakan 
dukungan bagi perawat maka tingkat stres kerja perawat akan meningkat sehingga mengganggu asuhan keperawatan dan meningkatkan risiko terjadinya nyeri punggung bawah.

Pada penelitian ini didapatkan bahwa hubungan persepsi perawat tentang kepuasan kerja dan nyeri punggung bawah punggung memiliki hubungan yang cukup kuat $(\mathrm{r}=0,401)$. Hasil ini sesuai dengan hasil suatu meta-analisis dengan penelitian skala besar oleh Farragher yang menyebutkan bahwa adanya hubungan yang kuat antara kepuasan kerja dan kesehatan mental dan fisik. ${ }^{31}$

Kepuasan kerja pada dasarnya adalah sikap pekerja terhadap pekerjaannya. ${ }^{32}$ Sama seperti semua sikap, kepuasan kerja terdiri dari perasaan, pikiran dan tingkah laku yang dimiliki individu terkait pekerjaan mereka. Sebagian besar penulis menekankan pada komponen emosional dari kepuasan kerja. Namun demikian, komponen kognitif dan tingkah laku dari kepuasan kerja merupakan komponen penting. Aspek kognitif kepuasan kerja mewakili kepercayaan pekerja akan situasi pekerjaan mereka, apakah pekerjaannya menarik, menstimulasi, suram atau sukar. Sedangkan komponen tingkah laku dari pekerja lebih sering merupakan kecenderungan akan tingkah laku mereka terhadap pekerjaan mereka.

Tabel 4. Distribusi Kategori Skor REBA Pemindahan Pasien Secara Lateral

\begin{tabular}{cccc}
\hline $\begin{array}{c}\text { Skor REBA } \\
\text { pemindahan } \\
\text { pasien secara } \\
\text { lateral }\end{array}$ & n $(\%)$ & Mean & $\begin{array}{c}\text { Standar } \\
\text { Deviasi }\end{array}$ \\
\cline { 1 - 1 } Sangat tinggi & $1(2,4 \%)$ & & \\
\cline { 1 - 1 } Tinggi & $20(48,8 \%)$ & & 1,762 \\
\hline Sedang & $20(48,8 \%)$ & & \\
\hline
\end{tabular}

Pemindahan pasien ke lateral diukur menggunakan instrumen sistem skor REBA. Berdasarkan tabel 4, risiko sedang dan tinggi memiliki frekuensi yang sama yaitu sebanyak 20 orang, dan sisanya 1 orang berkategori sangat tinggi. Pada analisis berikutnya, kategori risiko sangat tinggi dan risiko tinggi disatukan untuk menyederhanakan kategori. Bila dirata-rata keseluruhan skor REBA pemindahan pasien ke lateral perawat ICU dan ICCU di 3 rumah sakit tersebut memiliki kategori risiko tinggi.

Tabel 5. Distribusi Data Nyeri Punggung Bawah Perawat ICU dan ICCU Berdasarkan Kategori Skor REBA

\begin{tabular}{llc}
\hline \multirow{2}{*}{$\begin{array}{l}\text { Risiko } \\
\text { pemindahan }\end{array}$} & \multicolumn{2}{c}{ Nyeri punggung bawah } \\
\cline { 2 - 3 } & Ya (\%) & Tidak(\%) \\
\hline Tinggi & $19(67,9 \%)$ & $2(15,4 \%)$ \\
\hline Sedang & $9(32,1 \%)$ & $11(84,6 \%)$ \\
\hline Jumlah (\%) & $28(100 \%)$ & $13(100 \%)$ \\
\hline
\end{tabular}

Berdasarkan tabel 5, diketahui bahwa mayoritas perawat yang mengalami nyeri punggung bawah adalah perawat dengan risiko tinggi pada proses pemindahan pasien ke lateral. Berdasarkan skor REBA-nya, perawat yang paling banyak mengalami nyeri punggung bawah adalah perawat dengan skor REBA 8 dan 9 yaitu sebanyak masing-masing 7 dari 28 orang.

Tabel 6. Hasil Uji Koefisien Kontigensi Variabel Pemindahan Pasien Secara Lateral

Terhadap Keluhan Nyeri Punggung Bawah Perawat ICU dan ICCU.

\begin{tabular}{cc}
\hline Variabel & $\mathbf{r}$ \\
\hline Pemindahan pasien ke lateral & 0,439 \\
\hline
\end{tabular}

Hasil uji koefisien kontingensi tabel 6, diketahui bahwa nilai $r$ sebesar 0,440 yang berarti kuat hubungan antara persepsi perawat tentang kepuasan kerja dan nyeri punggung bawah perawat termasuk cukup kuat. Pada tabel $\mathrm{X}$ variabel pemindahan pasien secara lateral memiliki perbedaan rerata skor pemindahan pasien secara lateral antara kelompok perawat yang mengalami nyeri punggung bawah dan perawat yang tidak mengalami nyeri punggung bawah.

James A. Haley mengidentifikasi tugas yang berhubungan dengan gangguan muskuloskeletal pada 5 ICU. Kriteria yang digunakan untuk mengidentifikasi adalah 
memerlukan tenaga besar, sikap kerja tidak ergonomis dan pembebanan berulang. Dari hasil evaluasi didapatkan bahwa terdapat tujuh tugas patient handling yang berisiko tinggi menyebabkan gangguan muskuloskeletal, yaitu mendorong tempat tidur pasien, memindahkan pasien secara lateral, memindahkan pasien ke puncak tempat tidur, mereposisi pasien di tempat tidur, menyiapkan tempat tidur untuk pasien baru, memakaikan stocking anti emboli, dan mengangkat atau memindahkan peralatan yang berat. ${ }^{33}$ Selain aktivitas tersebut, terdapat aktivitas asuhan keperawatan lain yang berpotensi menimbulkan nyeri punggung bawah namun tidak ikut diobservasi dalam penelitian ini, seperti memeriksa tensi pasien, sampling darah pasien, menginjeksi obat.

Pada penelitian ini sebelum dilakukan penentuan tugas perawat yang akan dijadikan variabel, terlebih dahulu dilakukan pengisian lembar self report mengenai frekwensi aktivitas patient handling oleh perawat. Kemudian dihitung total frekwensinya jenis patient handling task yang paling sering dilakukan untuk dijadikan sebagai variabel independen penelitian. Dari hasil lembar self report, didapatkan pemindahan pasien secara lateral memiliki frekwensi tertinggi. Hal ini dilakukan untuk memudahkan dan lebih memfokuskan peneliti pada satu aktivitas patient handling yang akan diobservasi dan dinilai skor REBA-nya.

Sikap kerja tidak ergonomis adalah sikap kerja yang menyebabkan posisi bagian tubuh bergerak menjauhi posisi alamiah, misalnya pergerakan tangan terangkat, punggung terlalu membungkuk, kepala terangkat, dan sebagainya. Semakin jauh posisi tubuh dari pusat gravitasi tubuh maka akan semakin tinggi pula risiko terjadinya keluhan sistem muskuloskeletal. Sikap kerja tidak ergonomis ini pada umumnya karena karakteristik tuntutan tugas tidak sesuai dengan kemampuan dan keterbatasan pekerja. Pada penelitian ini didapatkan bahwa pemindahan pasien ke lateral dan nyeri punggung bawah punggung perawat memiliki hubungan yang cukup kuat $(\mathrm{r}=0,440)$.
Proses pemindahan pasien melibatkan beberapa gerakan, yaitu menarik, mendorong, mengangkat, fleksi dan ekstensi, kesemuanya menimbulkan pembebanan pada tulang belakang. Gerakan-gerakan tersebut secara individual sudah menimbulkan pembebanan pada tulang belakang, terlebih lagi jika dikombinasikan. Studi oleh Holterman, mengangkat dan membawa beban ringan yang sering dilakukan saat kerja dengan postur punggung agak membungkuk sudah dapat meningkatkan risiko terjadinya nyeri punggung bawah. ${ }^{34}$ Studi oleh Roffey menunjukkan bekerja dengan postur tidak ergonomis dapat menimbulkan beban statis pada jaringan lunak, akumulasi metabolit sehingga mempercepat proses degenerasi dan herniasi diskus tulang belakang. ${ }^{35}$ Pemindahan pasien yang dilakukan setiap hari berhubungan dengan cedera punggung pada pekerja kesehatan. ${ }^{36}$

Para perawat yang melakukan pemindahan pasien seringkali harus menjangkau pasien dengan mengulurkan lengannya, baik di awal maupun pada akhir proses pemindahan pasien dari satu permukaan ke permukaan lain (misal dari brangkart ke bed atau sebaliknya). Faktor risiko yang berpotensi ketika melakukan aktivitas pemindahan ini adalah besarnya gaya yang timbul ketika menarik dan mendorong serta terulurnya lengan. Aktivitas ini akan menjadi lebih susah ketika ketinggian perawat yang bekerja berbeda jauh atau ketika pasien menolak pemindahan (misal pada pasien yang sedang hilang kesadaran atau pasien dengan luka bedah). ${ }^{33,3}$

Akibat dari gaya dorong dan tarik yang sangat besar selama proses pemindahan pasien akan menimbulkan tingginya gaya potong dan gaya kompresi pada tulang belakang, yang mungkin bisa melampaui batas toleransi gaya potong dan gaya kompresi pada pembebanan tulang belakang dan punggung. Besarnya gaya yang dibutuhkan saat pemindahan pasien secara lateral tergantung pada berat badan pasien dan koefisien gesek dari permukaan geser, yaitu diukur dari derajat kelicinan antara pasien dan permukaan tempat tidur atau antara sprei dan 
permukaan tempat tidur. Semakin licin atau halus, maka gaya yang dibutuhkan semakin rendah. ${ }^{33}$

Data yang dirilis oleh Liberty Mutual Insurance Research Institute for Safety, menyebutkan bahwa nilai gaya tarik maksimum yang masih bisa diterima oleh wanita adalah 23 kilogram pada awal penarikan, nilai tersebut merupakan nilai maksimum untuk satu orang. Paparan pada pengangkatan beban lebih dari 25 kilogram dapat meningkatkan risiko insiden nyeri punggung bawah sebesar $4,3 \%$. Nilai gaya tarik yang sebenarnya pada proses pemindahan mungkin akan susah ditentukan. Untuk memudahkan maka dijelaskan bahwa tanpa adanya alat pengurang gaya gesek, gaya tarik yang dibutuhkan kurang lebih $75 \%$ dari berat badan pasien. Model terbaru dari sliding sheet, bisa mengurangi gaya tarik yang dibutuhkan hingga mencapai $25 \%$ saja. ${ }^{33,37}$

Pada proses pemindahan pasien di ketiga lokasi penelitian, semua perawat tidak menggunakan alat bantu khusus, selain menggunakan sprei atau perlak yang digunakan oleh pasien. Penggunaan sprei atau perlak mungkin membantu memudahkan proses pemindahan pasien namun belum tentu mengurangi risiko cedera muskuloskeletal khususnya nyeri punggung bawah. Kecenderungan terjadinya nyeri punggung bawah pada perawat dengan skor REBA yang tinggi pada penelitian ini bisa mengingatkan pentingnya penggunaan alat bantu patient handling. Widhawati menyebutkan bahwa hasil pengukuran REBA penggunaan alat bantu manual patient handling NMR dapat membantu memperbaiki postur tubuh perawat saat memindahkan pasien dari rata-rata potensi risiko tinggi menjadi berisiko rendah. ${ }^{38}$ Studi oleh Andersen menyatakan penggunaan yang konsisten terhadap alat bantu pemindahan pasien berhubungan dengan berkurangnya risiko cedera punggung pada pekerja kesehatan. ${ }^{39}$

Nilai REBA yang bervariasi dari sedang hingga tinggi sendiri juga bisa dimungkinkan karena belum adanya pelatihan mengenai aspek ergonomis dalam manual patient handling.
Masing-masing kepala ruangan menyatakan hal ini saat studi pendahuluan. Meski training ergonomi tidak menjadi variabel yang diteliti dalam penelitian ini, studi sebelumnya telah menunjukkan bahwa pelatihan pencegahan cedera di tempat kerja berhubungan dengan penurunan kemungkinan terjadinya cedera ketika proses pengangkatan oleh perawat. ${ }^{40}$ Pelatihan mengurangi deviasi tulang belakang dan aktivitas puncak otot dapat mengurangi beban pada punggung dan risiko cedera. Diperlukan pelatihan yang berkelanjutan supaya memastikan perawat dilatih dengan teori biomekanik yang tepat dan mempraktekkan gerakan tersebut untuk melindungi diri mereka dan pasiennya ketika tidak tersedia alat bantu saat melakukan proses manual patient handling dilakukan khususnya pemindahan pasien. ${ }^{41}$

\section{SIMPULAN DAN SARAN}

Dalam penelitian ini dapat disimpulkan bahwa nyeri punggung bawah perawat ICU dan ICCU memiliku hubungan yang kuat dengan persepsi perawat tentang tuntutan kerja, dukungan sosial, kepuasan kerja dan aktivitas pemindahan pasien secara lateral; hubungan yang lemah dengan persepsi perawat tentang kendali kerja. Saran bagi pengelola rumah sakit antara lain, untuk mengatasi persepsi perawat tentang tuntutan kerja dan kendali kerja, kepala ruangan perlu mengajak perawat pelaksana untuk membuat strategi kerja yang lebih efektif lagi; untuk mengatasi persepsi perawat tentang dukungan sosial, kepala ruangan perlu lebih memberikan dukungan dalam bentuk apresiasi bagi perawat dan menciptakan kerjasama antar perawat yang lebih baik ; Rumah sakit perlu melaksanakan pelatihan yang berkelanjutan mengenai aspek ergonomis postur kerja saat proses pemindahan pasien bagi para perawat ruangan instalasi rawat intensif.; rumah sakit perlu menyediakan alat bantu pemindahan pasien untuk mengurangi risiko nyeri punggung bawah pada perawat ruangan instalasi rawat intensif

Stres kerja dalam penelitian ini tidak termasuk dalam variabel yang diteliti, namun 
demikian stres kerja merupakan bagian dari proses timbulnya nyeri punggung bawah yang tidak bisa dihindari berdasarkan asumsi bahwa faktor psikososial dengan sendirinya berkontribusi menimbulkan stres. Penelitiam selanjutnya diharapkan dapat mengukur stres kerja yang ditimbulkan dari faktor psikososial.

\section{UCAPAN TERIMA KASIH}

Terimakasih disampaikan kepada pihak rumah sakit dan kepada para perawat ICU serta ICCU di 3 rumah sakit yang telah memberikan kesempatan dan meluangkan waktu untuk terlibat dalam penelitian ini.

\section{REFERENSI}

1. Balagué F, Mannion AF, Pellisé F, Cedraschi C. Non-specific low back pain. Lancet (London, England) [Internet]. 2012 Feb 4 [cited 2019 Oct 22];379(9814):482-91. Available from: http://www.ncbi.nlm.nih.gov/pubmed/219822 56

2. Hoy D, Brooks P, Blyth F, Buchbinder R. The Epidemiology of low back pain. Vol. 24, Best Practice and Research: Clinical Rheumatology. 2010. p. 769-81.

3. Wai EK, Roffey DM, Bishop P, Kwon BK, Dagenais S. Causal assessment of occupational lifting and low back pain: results of a systematic review. Spine J [Internet]. 2010 Jun 1 [cited 2019 Oct 22];10(6):554-66. Available from: http://www.ncbi.nlm.nih.gov/pubmed/204948 16

4. June KJ, Cho SH. Low back pain and workrelated factors among nurses in intensive care units. J Clin Nurs. 2011 Feb;20(3-4):479-87.

5. Daraiseh NM, Cronin SN, Davis LS, Shell RL, Karwowski W. Low back symptoms among hospital nurses, associations to individual factors and pain in multiple body regions. Int J Ind Ergon. 2010 Jan;40(1):1924.

6. Buchbinder R, Pransky G, Hayden J. Recent advances in the evaluation and management of nonspecific low back pain and related disorders. Best Pract Res Clin Rheumatol [Internet]. 2010 Apr [cited 2019 Oct 23];24(2):147-53. Available from: http://www.ncbi.nlm.nih.gov/pubmed/202276 37

7. Juniper M, Le TK, Mladsi D. The epidemiology, economic burden, and pharmacological treatment of chronic low back pain in France, Germany, Italy, Spain and the UK: A literature-based review. Vol. 10, Expert Opinion on Pharmacotherapy. 2009. p. 2581-92.

8. RA W, PG C, C D, H F, J I, U M-L, editors. Oxford textbook of rheumatology [Internet]. Oxford University Press; 2013. Available from:

https://oxfordmedicine.com/view/10.1093/me d/9780199642489.001.0001/med9780199642489

9. Krismer M, van Tulder M. Low back pain (non-specific). Vol. 21, Best Practice and Research: Clinical Rheumatology. 2007. p. 77-91.

10. Beynon $\mathrm{C}$, Leighton $\mathrm{D}$. Identification and measurement of risk. In: Reilly $\mathrm{T}$, editor. Muskuloskeletal disorders in health related occupation. IOS press; 2002.

11. Minematsu A. Epidemiology. In: Norasteh A, editor. Low back Pain. Croatia: Intech; 2012.

12. Marras W. The Working Back: A System View. New Jersey: John wiley \& Sons Inc.; 2008.

13. Tarwaka. Ergonomi Industri. Surakarta: Harapan pers; 2010.

14. Davis KG, Heaney CA. The relationship between psychosocial work characteristics and low back pain: Underlying methodological issues. Vol. 15, Clinical Biomechanics. Elsevier Science Ltd; 2000. p. 389-406.

15. Erez A. Psychosocial Factors in WorkRelated Musculoskeletal Disorders. In: Ergonomics for Therapists. Third. 2008. p. 123-136.

16. Eatough EM, Way JD, Chang C-H. Understanding the link between psychosocial work stresors and work-related musculoskeletal complaints. Appl Ergon [Internet]. 2012 May [cited 2019 Oct 24];43(3):554-63. Available from: http://www.ncbi.nlm.nih.gov/pubmed/219442 95

17. Bernal D, Campos-Serna J, Tobias A, VargasPrada S, Benavides FG, Serra C. Work-related psychosocial risk factors and musculoskeletal disorders in hospital nurses and nursing aides: a systematic review and meta-analysis. Int $\mathrm{J}$ Nurs Stud [Internet]. 2015 Feb [cited 2019 Oct 24];52(2):635-48. Available from: http://www.ncbi.nlm.nih.gov/pubmed/254804 59

18. Caplan R, Cobb S, French J, Van harrison R, Pinneau S. Job demands and Worker health. Washington DC: National Institute of occupational Safety and Health; 1975.

19. Almendra C. Relationship among job demand, job control, social support and job stres in registered nurse working in skilled nursing facilities [Internet]. University of New Jersey; 
2010. Available from: https://rucore.libraries.rutgers.edu/rutgerslib/27158/PDF/1/

20. Way M. Job demand, job control, and support: a comparison of three nursing work environments. [Internet]. Job Demand, Job Control \& Support: A Comparison of Three Nursing Work Environments. State University of New York at Buffalo; 2008 [cited 2019 Oct 24]. Available from: http://search.ebscohost.com/login.aspx?direct $=$ true $\& \mathrm{db}=\mathrm{jlh} \& \mathrm{AN}=109850763 \&$ site $=$ ehost live

21. Lang J, Ochsmann E, Kraus T, Lang JWB. Psychosocial work stresors as antecedents of musculoskeletal problems: a systematic review and meta-analysis of stability-adjusted longitudinal studies. Soc Sci Med [Internet]. 2012 Oct [cited 2019 Oct 24];75(7):1163-74. Available from: http://www.ncbi.nlm.nih.gov/pubmed/226826 63

22. Kanter R. Men and women of the corporation. New York: Basic Books, Inc.; 1993.

23. Karasek RA. Job Demands, Job Decision Latitude, and Mental Strain: Implications for Job Redesign. Adm Sci Q. 1979 Jun;24(2):285.

24. Karasek R, Theorell T. Healthy work. New York: Basic Books; 1990.

25. Cobb S. Social Support as a Moderator of Life Stress : Psychosomatic Medicine. Psychosom Med [Internet]. 1976 [cited 2019 Oct 24];38(5). Available from: https://journals.lww.com/psychosomaticmedic ine/Citation/1976/09000/Social_Support_as_a _Moderator_of_Life_Stress.3.aspx

26. Kossek EE, Pichler S, Bodner T, Hammer LB. Workplace social support and work-family conflict: A meta-analysis clarifying the influence of general and work-family-specific supervisor and organizational support. Pers Psychol. 2011 Jun;64(2):289-313.

27. Ozbay F, Johnson DC, Dimoulas E, Morgan CA, Charney D, Southwick S. Social support and resilience to stres: from neurobiology to clinical practice. Psychiatry (Edgmont) [Internet]. 2007 May [cited 2019 Oct 24];4(5):35-40. Available from: http://www.ncbi.nlm.nih.gov/pubmed/208060 28

28. Bradley JR, Cartwright S. Social support, job stres, health, and job satisfaction among nurses in the United Kingdom. Int J Stress Manag. 2002;9(3):163-82.

29. Cohen S, Wills TA. Stress, Social Support, and the Buffering Hypothesis. Vol. 98, Psychological Bulletin. 1985. p. 310-57.

30. Eisenberger NI, Taylor SE, Gable SL, Hilmert
CJ, Lieberman MD. Neural pathways link social support to attenuated neuroendocrine stres responses. Neuroimage. 2007 May 1;35(4):1601-12.

31. Faragher EB, Cass M, Cooper CL. The relationship between job satisfaction and health: A meta-analysis. Occup Environ Med. 2005 Feb;62(2):105-12.

32. Eagley A, Chaiken S. The psychology of attitudes. Fort Worth. Texas: Harcourt Brace Jovanovich College Publishers; 1993.

33. Waters TR, Nelson A, Proctor C. Patient Handling Tasks with High Risk for Musculoskeletal Disorders in Critical Care. Vol. 19, Critical Care Nursing Clinics of North America. 2007. p. 131-43.

34. Holtermann A, Clausen T, Aust B, Mortensen OS, Andersen LL. Risk for low back pain from different frequencies, load mass and trunk postures of lifting and carrying among female healthcare workers. Int Arch Occup Environ Health. 2013;86(4):463-70.

35. Roffey DM, Wai EK, Bishop P, Kwon BK, Dagenais S. Causal assessment of awkward occupational postures and low back pain: results of a systematic review. Vol. 10, Spine Journal. 2010. p. 89-99.

36. Andersen LL, Clausen T, Mortensen OS, Burr $\mathrm{H}$, Holtermann A. A prospective cohort study on musculoskeletal risk factors for long-term sickness absence among healthcare workers in eldercare. Int Arch Occup Environ Health. 2012 Aug;85(6):615-22.

37. Coenen P, Gouttebarge V, Van Der Burght ASAM, Van Dieën JH, Frings-Dresen MHW, Van Der Beek AJ, et al. The effect of lifting during work on low back pain: A health impact assessment based on a meta-analysis. Vol. 71, Occupational and Environmental Medicine. BMJ Publishing Group; 2014. p. 871-7.

38. Widhawati D. Pengaruh Alat Bantu Manual Patient Handling NMR (Studi Kasus pada Perawat terhadap Risiko dan Keluhan Musculoskeletal Disorders (MSDS) di Rumah Sakit Muji Rahayu). Universitas Airlangga; 2015.

39. Andersen LL, Burdorf A, Fallentin N, Persson $\mathrm{R}$, Jakobsen MD, Mortensen OS, et al. Patient transfers and assistive devices: Prospective cohort study on the risk for occupational back injury among healthcare workers. Scand J Work Environ Heal. 2014;40(1):74-81.

40. D'Arcy LP, Sasai Y, Stearns SC. Do assistive devices, training, and workload affect injury incidence? Prevention efforts by nursing homes and back injuries among nursing assistants. J Adv Nurs [Internet]. 2012 Apr [cited 2019 Oct 24];68(4):836-45. Available 
Vol. 1, No. 1, Nopember 2019, hlm. 57-68

DOI https://doi.org/10.37148/arteri.v1i1.21

from:

http://www.ncbi.nlm.nih.gov/pubmed/217873 70

41. Hodder JN, MacKinnon SN, Ralhan A, Keir PJ. Effects of training and experience on patient transfer biomechanics. Int J Ind Ergon. 2010 May;40(3):282-8. 